\title{
Gas chromatography-mass- spectroscopy analysis of bioactive compounds from Streptomyces spp. isolated from Tigris river sediments in Baghdad city
}

\author{
Talib Saleh Al-Rubaye Mohsen Hashim Risan* Dalal Al-Rubaye \\ Biotechnology department / College of Science / University of Baghdad \\ * Biotechnology College /ALNahrain University \\ E-mail: dr.tbdalal@gmail.com
}

\begin{abstract}
Background:The Streptomyces are considered the most important bacterial source for bioactive compounds production including natural antibiotics.

Objective: This study focused on analysis of these products to characterize the most active substances which may contain new antibiotics.
\end{abstract}

Materials and methods: Samples with the highest antibacterial activities (21, M5, N- and D-) were chosen from a previous study after secondary screening for the intracellular (biomass) extract which showed more antagonism efficiency than that observed in extracellular crude extract.Gas chromatography - mass spectroscopy (GC-MS) was preformed to detect the structure of the compounds in intracellular crude extracts in these isolates.

Results: The GC-MS analysis showed a total of 49 peaks observed in 4 isolates, isolate M5=14 peaks, isolate $\mathrm{D}=11$ peaks, isolate $\mathrm{N}=20$ peaks and isolate $21=4$ peaks. Isolate $\mathrm{D}$-, which showed the highest zone of inhibition in secondary screening than that in other isolates, is associated with the most prevalence active compounds like the Decane derivatives, in addition to Triadimenol; Azetidine, 1-(1,1dimethylethyl)-3-methyl; Hexanoic acid, 2-ethyl-, 2-ethylhexyl ester and 3,3,7,7-Tetramethyl-1,5diazabicyclo(3.3.0)octane. While isolate 21, has less peaks in comparing with the other samples, with great occurrence in components: 1-Dimethylaminohexane with molecular formula C8H19N and molecular weight 129 and Propamocarb with molecular formula C9H20N2O2 and molecular weight 188, in addition to many volatile organic compounds. The greatest components of isolate M5 were Triadimenol and 3,3,7,7-Tetramethyl-1,5-diazabicyclo(3.3.0)octane, in addition to the presence of Decane derivatives; amine compounds and Vitamin E. Isolate $\mathrm{N}$ - showed a great occurrence with components Triadimenol and Azetidine, 1-(1,1-dimethylethyl)-3-methyl-with a molecular formula C8H17N and with a molecular weight 127; also the presence of an important component Hexanoic acid, 2-methyl- with the molecular formula $\mathrm{C7H14O2}$ and with molecular weight 103 which has been considered as an essential component of muramycin antibiotic; compounds which contain Benzene ring.

Conclusion: The most prominent compounds detected in the selected isolates by using GC-MS technique were Decane derivatives and Triadimenol.

Keywords: Streptomyces , GC-chromatography- mass spectroscopy , molecular formula , Intracellular crude extract. 


\section{Introduction}

Actinomycetes constitute a significant component of the microbial population in most soils and the most important member of the actinomycetes is the genus Streptomyces which accounts for $80 \%$ of the total Actinomycetes population (1). The genus Streptomyces is aerobic and spore forming Actinomycetes and recognized as highly producing of useful bioactive metabolites with broad spectrum activities, such as antibacterial, antifungal, antibiotic, antiparasitic, antitumor and antiviral, immunomodulators agents $(2,3)$. They form approximately $80 \%$ of the total antibiotic products as compared to other actinomycetes genera and considered to be the major source of bioactive secondary metabolites and antibiotics producer, forming more than half of the naturally produced antibiotics $(3,4)$. The needs for new and novel antibiotic is related to increasing the antimicrobial resistance worldwide in an alarming rate and the emergency of drug resistant pathogens which cause life threatening infections especially in immunodeficient patients, increase toxicity of currently used compounds and the evolution of new diseases $(5,6)$. Evaluation and characterization of these bioactive compounds determined by many methods like High Performance Liquid Chromatography (HPLC), Nuclear Magnetic Resonance spectroscopy (NMR) and Gas Chromatography Mass Spectroscopy (GC-MS) (7). However, the extracellular crude of actinomycetes in most studies were evaluated and characterized, but an observation by $(7,8)$ found that the intracellular crude extract of actinomycetes isolates had more antagonism activities against pathogenic microorganisms than extracellular crude which need for further investigations. GC-MS is an apparatus that used to identify the components in a mixture like hydrocarbons, essential oils and solvents. The electron capture detector and a flame ionization detector can quantitatively determine the materials even very low concentrations. It is widely used especially in biochemistry because of its simplicity, sensitivity, and effectiveness in separating components of mixtures quantitatively and qualitatively to fix thermo chemical standards as heats of solution and vaporization, vapor pressure, activity coefficients and for purification of compounds (9,10). The GC-MS is important in medicinal chemistry researches, pharmaceutical analysis, pharmacognosy, pharmaceutical biotechnology and pharmaceutical process control (11)._This study was aimed to identify the chemical constituents in intracellular crude extract of actinomycetes isolated from river sediments by GC-MS method.

\section{Materials and Methods Soil samples collection}

Semi-purified intracellular crude extract collected from a previous study (7) as follows: the separation of the intracellular crude from the extracellular crude were done by centrifugation. The bacterial pellets in the tube contained intracellular antimicrobial metabolites. The intracellular antimicrobial activities were determined by agar well diffusion as follows: the pelleted cells were re-suspended in the test tube containing lysis buffer $1 \mathrm{ml} \mathrm{TE}$ buffer Tris $200 \mathrm{ml}$ and $50 \mathrm{ml}$ EDTA, $60 \mu \mathrm{l}$ of 10\% SDS and $6 \mu \mathrm{l}$ of proteinase K, with a gentle shaking, the mixture incubated at $37^{\circ} \mathrm{C}$ for 60 minutes. The intracellular metabolites liberated after bacterial cell walls disruption. Six hundred $\mu$ of the intracellular crude metabolites was taken and mixed with $600 \mu \mathrm{l}$ of methanol. The mixture was gently mixed and left for 60 minutes. Then the tubes were spun at 1000rpm for 10 minutes at room temperature. The mixture was separated into two phases, the upper phase methanolic phase containing dissolved metabolites, was collected and transferred to the sterilized petri dish, then kept in a hot air oven $45^{\circ} \mathrm{C}$ for 24 hours to dry the dissolved intracellular crude extract. Finally, the dried intracellular crude extracts were dissolved in double volume of sterilized distal water $(1200 \mu 1)$ then analyzed to determine the bioactive compounds through using the GC-Mass. 


\section{Gas chromatography - mass spectroscopy (GC - MS) analysis of bioactive metabolite}

The GC-mass chromatography analysis was performed to identify the active antibacterial compounds in the intracellular extract. Identification of bioactive compounds was done by injecting $1 \mu 1$ of sample into an RT * 5 column $(30 * 0.32 \mathrm{~nm}$ ) of GC-MS model (Perkin Elmer, Clarus 500, USA); helium ( $3 \mathrm{ml} / \mathrm{min})$ was used as a carrier gas. The following temperature gradient program was used $\left(75^{\circ} \mathrm{C}\right.$ for 2 min followed by an increase from 75 to $175{ }^{\circ} \mathrm{C}$ at a rate of $50{ }^{\circ} \mathrm{C}$ per min and finally $7 \mathrm{~min}$ at $175^{\circ} \mathrm{C}$ ). The $\mathrm{m} / \mathrm{z}$ peaks representing mass to charge ratio characteristics of the antibacterial fractions were compared to those in the mass spectrum library of the corresponding organic compounds (12). This experiment was conducted in Science and Technology Ministry.

\section{Results and discussion}

\section{GC- Mass analysis of antibacterial metabolites}

The intracellular crude extracts were analyzed by GC-MS. Mass spectrum of GC-MS was interpreted according to the National Institute Standard and Technology (NIST) database, by comparing the spectrum unknown with the known data stored in NIST library. The name, molecular weight and structure of the components of the test materials were ascertained $(13,14)$. A total of 49 peaks was observed from 4 samples, sample M5=14 peaks, D=11peaks, N= 20 peaks and 21=4peaks (Figure 1a, b, c and d).

A

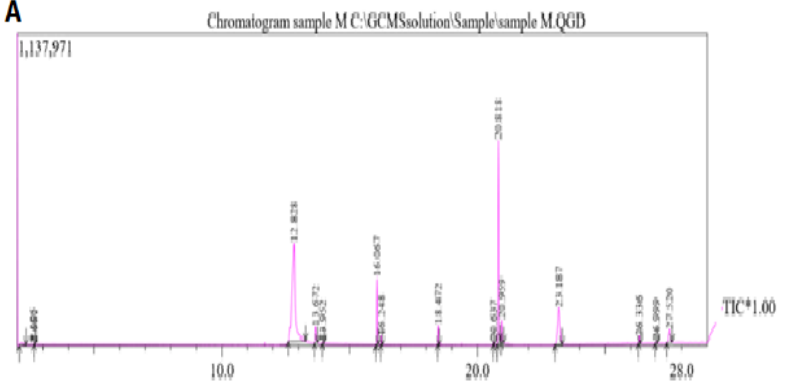

B

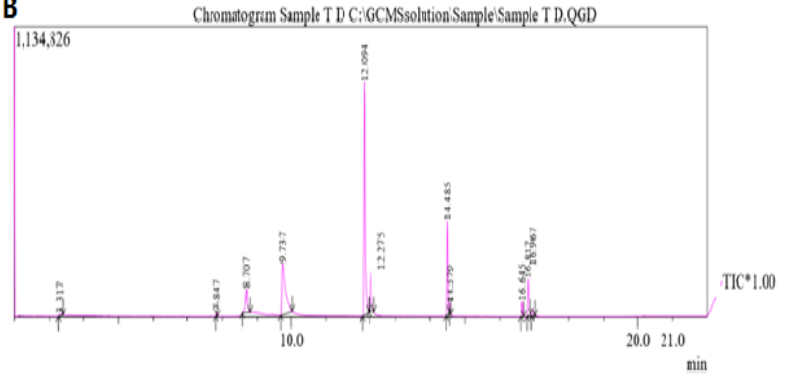

C

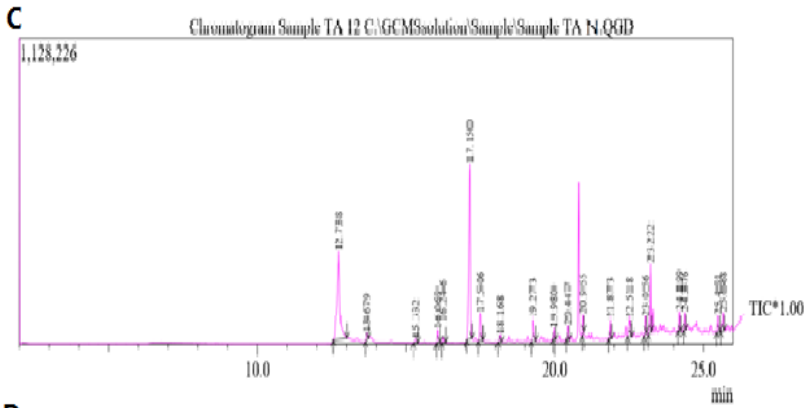

D

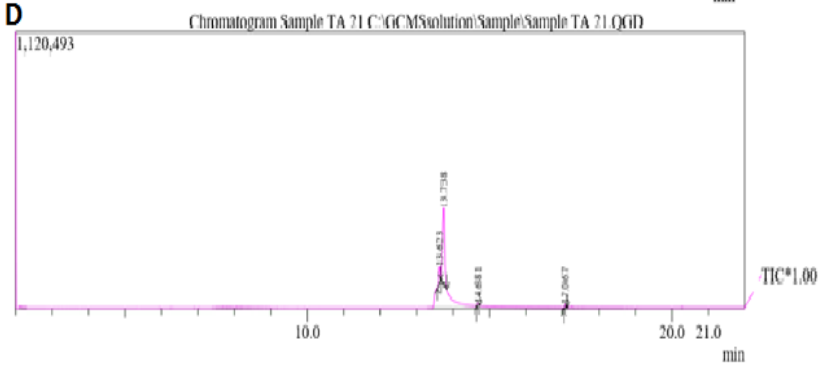

Figure (1): GC-MS chromatography of intracellular extract of Streptomyces spp. Isolates: M5 (A), sample $\mathrm{D}^{-},(\mathrm{B})$ sample $\mathrm{N}^{-}(\mathrm{C})$ and sample 21 (D) showed the presence of many peaks (Table 1,2,3and 4)

In comparison with the constituents of the NIST library, 49 peaks were predicted and the compounds were identified as antibacterial and bioactive compounds for each sample. These identified compounds may play as the major constituents alone or with minor constituents provided as antimicrobial bioactive compounds. The data of isolate $\mathrm{D}^{-}$Table (1), which formerly showed the highest zone of inhibition more than other isolates, revealed the occurrence of the major component Tetradecane, 1-iodo- with the molecular formulas 
of $\mathrm{C}_{14} \mathrm{H}_{29} \mathrm{I}$ and with molecular weight 324 . The same results were observed by Nandhini and his colleagues (15). She observed the antimicrobial activity of this component produced from marine Streptomyces. The major second component was Dodecane, with the molecular formulas of $\mathrm{C}_{12} \mathrm{H}_{26}$ and with molecular weight $170,(16)$ showed the same results. Decane is the prevalent component, which appeared in most peaks with a little difference either as iodio and chloro in addition to one component with bromo. This results in agreement with (17). In addition to Triadimenol, it is a fungicide with molecular formula $\mathrm{C}_{14} \mathrm{H}_{18} \mathrm{ClN}_{3} \mathrm{O}_{2}$ and molecular weight 295, was reported also by (18). An important component Azetidine, 1-(1,1-dimethylethyl)3-methyl- with a molecular formula $\mathrm{C}_{8} \mathrm{H}_{17} \mathrm{~N}$ and with a molecular weight 127 has Azetidine as a basic unit which reported by (19), but with a little difference related to environmental pressure. They showed that the bonnevillamides were produced from Streptomyces spp isolated from Great Salt Lake sediment, which was considered as a new class of heptapetides showing novel amino acid residues that have 4-methylazetidine-2-carboxylic acid methyl ester moiety. The peptide was associated and affected zebrafish embryo development, also controlling the growth and function of the heart. Hexanoic acid, 2-ethyl-, 2ethylhexyl ester contain the short chain fatty acid (Hexanoic acid), which has an antibacterial activity as reported by (20).

Table (1): GC mass profile of the intracellular extraction of Streptomyces sample D-

\begin{tabular}{|c|c|c|c|c|c|c|c|}
\hline No. & $\begin{array}{c}\text { R.t } \\
(\mathbf{m i n})\end{array}$ & Compounds & activity & M. formula & $\begin{array}{c}\text { M.W } \\
\text { (g/mole) }\end{array}$ & $\begin{array}{c}\text { Area } \\
\%\end{array}$ & $\underset{\%}{\text { R.A }}$ \\
\hline 1 & 2.094 & Tetradecane, 1-iodo- & $\begin{array}{c}\text { Antibacterial and } \\
\text { bioactive }\end{array}$ & $\mathrm{C}_{14} \mathrm{H}_{29} \mathrm{I}$ & 324 & 39.20 & 45.33 \\
\hline 2 & 2.094 & 1-Iodoundecane & $\begin{array}{c}\text { Antibacterial and } \\
\text { bioactive }\end{array}$ & $\mathrm{C}_{11} \mathrm{H}_{23} \mathrm{I}$ & 282 & 39.20 & 45.33 \\
\hline 3 & 2.094 & Dodecane, 1-iodo- & bioactive & $\mathrm{C}_{12} \mathrm{H}_{25} \mathrm{I}$ & 296 & 39.20 & 45.33 \\
\hline 4 & 2.094 & Dodecane & $\begin{array}{c}\text { Antibacterial } \\
\text { Bioactive }\end{array}$ & $\mathrm{C}_{12} \mathrm{H}_{26}$ & 170 & 39.20 & 45.33 \\
\hline 5 & 12.094 & 2-Bromo dodecane & Bioactive & $\mathrm{C}_{12} \mathrm{H}_{25} \mathrm{Br}$ & 248 & 39.20 & 45.33 \\
\hline 6 & 14.485 & Tridecane, 1-iodo- & $\begin{array}{c}\text { Antibacterial and } \\
\text { bioactive }\end{array}$ & $\mathrm{C}_{13} \mathrm{H}_{27} \mathrm{I}$ & 310 & 14.485 & 18.22 \\
\hline 8 & 9.737 & 1-Chloroundecane & $\begin{array}{l}\text { Antibacterial and } \\
\text { bioactive }\end{array}$ & $\mathrm{C}_{11} \mathrm{H}_{23} \mathrm{Cl}$ & 190 & 24.02 & 9.95 \\
\hline 9 & 9.737 & Decane, 1-chloro- & $\begin{array}{c}\text { Antibacterial and } \\
\text { bioactive }\end{array}$ & $\mathrm{C}_{10} \mathrm{H}_{21} \mathrm{Cl}$ & 176 & 24.02 & 9.95 \\
\hline 10 & 9.737 & Nonane, 1-chloro- & $\begin{array}{c}\text { Antibacterial and } \\
\text { bioactive }\end{array}$ & $\mathrm{C}_{9} \mathrm{H}_{19} \mathrm{Cl}$ & 162 & 24.02 & 9.95 \\
\hline 11 & 9.737 & $\begin{array}{c}\text { Tetradecane, } 1 \text { - } \\
\text { chloro- }\end{array}$ & $\begin{array}{c}\text { Antibacterial and } \\
\text { bioactive }\end{array}$ & $\mathrm{C}_{14} \mathrm{H}_{29} \mathrm{Cl}$ & 232 & 24.02 & 9.95 \\
\hline 12 & 9.737 & Dodecane, 1-chloro & $\begin{array}{c}\text { Antibacterial and } \\
\text { bioactive }\end{array}$ & $\mathrm{C}_{12} \mathrm{H}_{25} \mathrm{Cl}$ & 204 & 24.02 & 9.95 \\
\hline 13 & 16.817 & Triadimenol & & $\mathrm{C}_{14} \mathrm{H}_{18} \mathrm{ClN}_{3} \mathrm{O}_{2}$ & 295 & 5.48 & 7.07 \\
\hline 14 & 16.817 & $\begin{array}{c}\text { Azetidine, 1-(1,1- } \\
\text { dimethylethyl)-3- } \\
\text { methyl- }\end{array}$ & $\begin{array}{c}\text { Antibacterial and } \\
\text { bioactive }\end{array}$ & $\mathrm{C}_{8} \mathrm{H}_{17} \mathrm{~N}$ & 127 & 5.48 & 7.07 \\
\hline 15 & 16.817 & $\begin{array}{c}\text { Hexanoic acid, 2- } \\
\text { ethyl-, 2-ethylhexyl } \\
\text { ester }\end{array}$ & $\begin{array}{c}\text { Antibacterial and } \\
\text { bioactive }\end{array}$ & $\mathrm{C}_{16} \mathrm{H}_{32} \mathrm{O}_{2}$ & 256 & 5.48 & 7.07 \\
\hline
\end{tabular}




\begin{tabular}{|c|c|c|c|c|c|c|c|}
\hline 16 & 16.817 & $\begin{array}{c}3,3,7,7-\text { Tetramethyl- } \\
1,5- \\
\text { diazabicyclo(3.3.0)oct } \\
\text { ane }\end{array}$ & $\begin{array}{c}\text { Antibacterial and } \\
\text { bioactive }\end{array}$ & $\mathbf{C}_{10} \mathrm{H}_{20} \mathbf{N}_{2}$ & 168 & 5.48 & 7.07 \\
\hline
\end{tabular}

$\mathbf{R A}=$ peak area of each compound / the highest peak aerea $* 100$

Sample M5 Table (2) that showed the greatest component was Triadimenol with molecular formula $\mathrm{C}_{14} \mathrm{H}_{18} \mathrm{ClN}_{3} \mathrm{O}_{2}$ and molecular weight 295. This fungicide was reported also by (18). The other great component was 3,3,7,7-Tetramethyl-1,5-diazabicyclo(3.3.0)octane with molecular formula $\mathrm{C}_{10} \mathrm{H}_{20} \mathrm{~N}_{2}$ and molecular weight 168 , in spite of its match in NIST with $100 \%$ but there is no study that shows the antagonism activity of this component as a Streptomyces product. Decane as heptadecane and tridecane was in an agreement with the results reported by (15). Tetradecane, 1-iodo-, and 1-Iodoundecane, are represented with a lower relative abundance than in sample D. This strain produced vitamin E with a molecular weight 430 , molecular formula $\mathrm{C}_{29} \mathrm{H}_{50} \mathrm{O}_{2}$ and the name 2H-1-Benzopyran-6-ol, 3,4-dihydro-2,5,7,8-tetramethyl-2-(4,8,12-trimethyltridecyl),$(2 \mathrm{R}-(2 \mathrm{R} *(4 \mathrm{R} *, 8 \mathrm{R} *)))-$. The tocopherol is a basic unit in vitamin $\mathrm{E}$ and the tocopherols biotransformation by Streptomyces catenulae were studied by (21).

Table (2): GC mass profile of the intracellular extraction of Streptomyces sample M5

\begin{tabular}{|c|c|c|c|c|c|c|c|}
\hline No. & $\begin{array}{c}\text { R.t } \\
(\mathbf{m i n})\end{array}$ & Compound & Activity & M. formula & $\begin{array}{c}\text { M.W } \\
\text { (g/mole) }\end{array}$ & $\begin{array}{c}\text { Area } \\
\%\end{array}$ & $\begin{array}{c}\text { (R A) } \\
\%\end{array}$ \\
\hline 1. & 20.818 & Triadimenol & $\begin{array}{l}\text { Bioactive } \\
\text { Fungicide }\end{array}$ & $\mathrm{C}_{14} \mathrm{H}_{18} \mathrm{ClN}_{3} \mathrm{O}_{2}$ & 295 & 22.13 & 40.47 \\
\hline 2. & 20.818 & $\begin{array}{l}\text { 3,3,7,7- } \\
\text { Tetramethyl-1,5- } \\
\text { diazabicyclo(3.3. } \\
\text { 0)octane }\end{array}$ & $\begin{array}{l}\text { Bioactive } \\
\text { In NIST } \\
\text { pubchem but no } \\
\text { articles as } \\
\text { antibiotic. }\end{array}$ & $\mathrm{C}_{10} \mathrm{H}_{20} \mathrm{~N}_{2}$ & 168 & 22.13 & 40.47 \\
\hline 3. & 12.828 & $\begin{array}{l}\text { N,1- } \\
\text { Dimethylhexyla } \\
\text { mine }\end{array}$ & $\begin{array}{l}\text { Antibacterial } \\
\text { and Bioactive } \\
\text { Just in NIST }\end{array}$ & $\mathrm{C}_{8} \mathrm{H}_{19} \mathrm{~N}$ & 129 & 45.37 & 19.59 \\
\hline 4. & 12.828 & $\begin{array}{l}\text { Ethanamine, } \\
\text { 2,2'-oxybis(N,N- } \\
\text { dimethyl- }\end{array}$ & bioactive & $\mathrm{C}_{8} \mathrm{H}_{20} \mathrm{~N}_{2} \mathrm{O}$ & 160 & 45.37 & 19.59 \\
\hline 5. & 12.828 & $\begin{array}{l}\text { 1,2- } \\
\text { Ethanediamine, } \\
\text { N,N'-diethyl- }\end{array}$ & bioactive & $\mathrm{C}_{6} \mathrm{H}_{16} \mathrm{~N}_{2}$ & 116 & 45.37 & 19.59 \\
\hline 6. & 16.067 & $\begin{array}{l}\text { Tetradecane, 1- } \\
\text { iodo- }\end{array}$ & $\begin{array}{l}\text { Bioactive } \\
\text { And } \\
\text { antibacterial }\end{array}$ & $\mathrm{C}_{14} \mathrm{H}_{29} \mathrm{I}$ & 324 & 6.33 & 13.34 \\
\hline 7. & 16.067 & 1-Iodoundecane & $\begin{array}{l}\text { Bioactive } \\
\text { And } \\
\text { antibacterial }\end{array}$ & $\mathrm{C}_{11} \mathrm{H}_{23} \mathrm{I}$ & 282 & 6.33 & 13.34 \\
\hline 8. & 16.067 & $\begin{array}{l}\text { Heptadecane, } \\
\text { 2,6-dimethyl- }\end{array}$ & $\begin{array}{l}\text { Bioactive } \\
\text { And } \\
\text { antibacterial }\end{array}$ & $\mathrm{C}_{19} \mathrm{H}_{40}$ & 268 & 6.33 & 13.34 \\
\hline 9. & 16.067 & $\begin{array}{l}\text { Nonane, 3,7- } \\
\text { dimethyl }\end{array}$ & Bioactive & $\mathrm{C}_{11} \mathrm{H}_{24}$ & 156 & 6.33 & 13.34 \\
\hline
\end{tabular}




\begin{tabular}{|l|l|l|l|c|c|l|l|}
\hline 10. & 16.067 & $\begin{array}{l}\text { Tridecane, 1- } \\
\text { iodo- }\end{array}$ & $\begin{array}{l}\text { Bioactive } \\
\text { And } \\
\text { antibacterial }\end{array}$ & $\mathrm{C}_{13} \mathrm{H}_{27} \mathrm{I}$ & 310 & 6.33 & 13.34 \\
\hline 11. & 23.187 & Vitamin $\mathrm{E}$ & bioactive & $\mathrm{C}_{29} \mathrm{H}_{50} \mathrm{O}_{2}$ & 430 & 12.45 & 7.27 \\
\hline
\end{tabular}

$\mathbf{R A}=$ peak area of each compound / the highest peak area $* 100$

Sample 21 Table (3) showed the lowest peaks in comparison with the other samples. The great occurrence was with component 1-Dimethylaminohexane with molecular formula $\mathrm{C}_{8} \mathrm{H}_{19} \mathrm{~N}$ and molecular weight 129 and Propamocarb with molecular formula $\mathrm{C}_{9} \mathrm{H}_{20} \mathrm{~N}_{2} \mathrm{O}_{2}$ and molecular weight 188. Regarding the component 1-Hexanol, 4-methyl-, with a molecular weight $\mathrm{C}_{7} \mathrm{H}_{16} \mathrm{O}$, this component was suggested to play an important role in plant growth promotion according to more recent research (22). Several studies have described the antifungal activity by bacterial volatile organic compounds (VOCs) however; few have identified single or blends of VOCs responsible for the antifungal activity (22). The VOCs are very important and there is a strong relationship between the VOCs and the spore production in Streptomyces, as reported by (23). They showed that the 2-methyl-1-butanol with the molecular formula $\mathrm{C}_{5} \mathrm{H}_{12} \mathrm{O}$ could be used to detect the heterogeneous substrates activity of these microorganisms.

\begin{tabular}{|c|c|c|c|c|c|c|c|}
\hline No & $\begin{array}{c}\begin{array}{c}\text { R.t } \\
(\mathbf{m i n})\end{array} \\
\end{array}$ & Compound & Activity & M. formula & $\begin{array}{c}\text { M.W } \\
(\mathrm{g} / \mathrm{mole})\end{array}$ & $\begin{array}{c}\text { Area } \\
\%\end{array}$ & $\begin{array}{c}\text { R.A } \\
\%\end{array}$ \\
\hline 1. & 13.62 & $\begin{array}{l}\text { 1,2-Ethanediamine, } \\
\text { N,N'-diethyl- }\end{array}$ & bioactive & $\mathrm{C}_{6} \mathrm{H}_{16} \mathrm{~N}_{2}$ & 116 & 12.45 & 15.92 \\
\hline 2. & 13.62 & $\begin{array}{l}\text { Ethanamine, 2,2'- } \\
\text { oxybis(N,N-dimethyl- }\end{array}$ & bioactive & $\mathrm{C}_{8} \mathrm{H}_{20} \mathrm{~N}_{2} \mathrm{O}$ & 160 & 12.45 & 15.92 \\
\hline 3. & 13.62 & $\begin{array}{l}\text { 1,2-Ethanediamine, } \\
\text { N,N-dimethyl- }\end{array}$ & bioactive & $\mathrm{C}_{4} \mathrm{H}_{12} \mathrm{~N}_{2}$ & 88 & 12.45 & 15.92 \\
\hline 4. & 13.62 & $\begin{array}{l}\text {-Propanol, 3- } \\
\text { (dimethylamino)- }\end{array}$ & bioactive & $\mathrm{C}_{5} \mathrm{H}_{13} \mathrm{NO}$ & 103 & 12.45 & 15.92 \\
\hline 5. & 13.73 & $\begin{array}{l}\text { 1- } \\
\text { Dimethylaminohexane }\end{array}$ & $\begin{array}{l}\text { Antibiotic } \\
\text { and } \\
\text { bioactive }\end{array}$ & $\mathrm{C}_{8} \mathrm{H}_{19} \mathrm{~N}$ & 129 & 83.33 & 77.32 \\
\hline 6. & 13.73 & Propamocarb & $\begin{array}{l}\text { Antifungal } \\
\text { bioactive }\end{array}$ & $\mathrm{C}_{9} \mathrm{H}_{20} \mathrm{~N}_{2} \mathrm{O}_{2}$ & 188 & 83.33 & 77.32 \\
\hline 7. & 17.067 & 1-Hexanol, 4-methyl- & bioactive & $\mathrm{C}_{7} \mathrm{H}_{16} \mathrm{O}$ & 116 & 2.27 & 3.92 \\
\hline 8. & 17.067 & 1-Butanol, 2-methyl- & bioactive & $\mathrm{C}_{5} \mathrm{H}_{12} \mathrm{O}$ & 88 & 2.27 & 3.92 \\
\hline 9. & 17.067 & $\begin{array}{l}\text { Nitroxide, bis(1,1- } \\
\text { dimethylethyl) }\end{array}$ & bioactive & $\mathrm{C}_{8} \mathrm{H}_{18} \mathrm{NO}$ & 144 & 2.27 & 3.92 \\
\hline 10. & 17.067 & Butyl trifluoroacetate & bioactive & $\mathrm{C}_{6} \mathrm{H}_{9} \mathrm{~F}_{3} \mathrm{O}_{2}$ & 170 & 2.27 & 3.92 \\
\hline
\end{tabular}




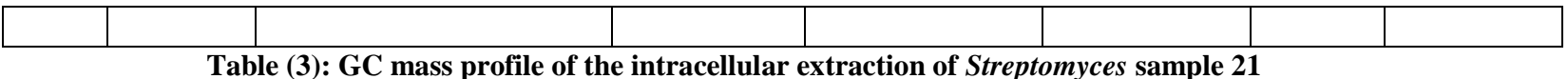

Table (3): GC mass profile of the intracellular extraction of Streptomyces sample 21

RA= peak area of each compound / the highest peak area *100

Regarding sample $\mathrm{N}^{-}$Table(4), the component Hexanoic acid, 2-methyl- with the molecular formula $\mathrm{C}_{7} \mathrm{H}_{14} \mathrm{O}_{2}$ and with molecular weight 103 was found as an essential component of muramycin antibiotic produced from Streptomyces (24). (25) showed that 2 -methyl -Propanoic acid produced from molds has been identified as having antifungal properties. An important component Azetidine, 1-(1,1-dimethylethyl)-3-methyl- with a molecular formula $\mathrm{C}_{8} \mathrm{H}_{17} \mathrm{~N}$ and with a molecular weight 127 has a Azetidine as a basic unit reported by (19). With little differences related to environmental pressure, they showed that a chemical investigation of Streptomyces spp. isolated from sediment collected from the Great Salt Lake led to the isolation of bonnevillamides. The bonnevillamides represent a new class of linear heptapetides featuring novel amino acid residues containing an extremely rare 4-methyl-azetidine-2-carboxylic acid methyl ester moiety. The peptide was evaluated for its effects on zebrafish embryo development and shown to modulate heart growth and cardiac function. (26) Showed the presence of 1,2-Benzenedicarboxylic acid, diisooctyl ester with molecular weight 390 and molecular formula $\mathrm{C}_{24} \mathrm{H}_{38} \mathrm{O}_{4}$ that has antimicrobial activity and anti- fouling produced from secondary metabolites of marine Streptomyces parvulus. This bacterium was isolated from the mangrove sediments in South Andaman Islands. (27) they found that 1,2-Benzenedicarboxylic acid, mono(2ethylhexyl) ester with molecular weight 278 and molecular formula $\mathrm{C}_{16} \mathrm{H}_{22} \mathrm{O}_{4}$, isolated from marine Streptomyces cavourensis has cytotoxicity against partially four selected immortal cell lines. A similar study showed that the 1, 2-Benzenedicarboxylic acid bis (2-ethylhexyl) phthalate naturally occurs and is isolated from a marine alga known Sargassum weighti. It has an antibacterial effect on many types of bacteria. In conclusion, the intracellular crude extract from isolates with the highest antibacterial activity (M5, N-, 21 and D-) characterized by GC-MS analysis revealed that metabolites mainly comprised of amides, amines, quinones and hydrocarbons.

Table (4): GC mass profile of the intracellular extraction of Streptomyces sample $\mathbf{N}^{-}$

\begin{tabular}{|c|c|c|c|c|c|c|c|}
\hline No. & R.t (min) & Compounds & Activity & M. formula & $\begin{array}{c}\text { M.W } \\
\text { (g/mole) }\end{array}$ & $\begin{array}{c}\text { Area } \\
\%\end{array}$ & $\begin{array}{c}(\mathbf{R} \mathbf{A}) \\
\%\end{array}$ \\
\hline 1. & 12.742 & $\begin{array}{l}\text { Hexanoic acid, 2- } \\
\text { methyl- }\end{array}$ & $\begin{array}{l}\text { Bioactivities } \\
\text { and } \\
\text { antibacterial }\end{array}$ & $\mathrm{C}_{7} \mathrm{H}_{14} \mathrm{O}_{2}$ & 130 & 27.96 & 14.65 \\
\hline 2. & 12.742 & $\begin{array}{l}\text { Butanoic acid, 2- } \\
\text { ethyl-2-methyl- }\end{array}$ & $\begin{array}{l}\text { Bioactive } \\
\text { antioxidant }\end{array}$ & $\mathrm{C}_{7} \mathrm{H}_{14} \mathrm{O}_{2}$ & 130 & 27.96 & 14.65 \\
\hline 3. & 12.742 & $\begin{array}{l}\text { N,N'- } \\
\text { Methylenebis(forma } \\
\text { mide) }\end{array}$ & Bioactive & $\mathrm{C}_{3} \mathrm{H}_{6} \mathrm{~N}_{2} \mathrm{O}_{2}$ & 102 & 27.96 & 14.65 \\
\hline 4. & 12.742 & $\begin{array}{l}\text { Propanoic acid, 3- } \\
\text { hydroxy-, methyl } \\
\text { ester }\end{array}$ & bioactive & $\mathrm{C}_{4} \mathrm{H}_{8} \mathrm{O}_{3}$ & 104 & 27.96 & 14.65 \\
\hline 5. & 17.150 & Triadimenol & Antifungal & $\mathrm{C}_{14} \mathrm{H}_{18} \mathrm{ClN}_{3} \mathrm{O}_{2}$ & 295 & 30.90 & 29.66 \\
\hline 6. & 17.150 & $\begin{array}{l}\text { Azetidine, 1-(1,1- } \\
\text { dimethylethyl)-3- }\end{array}$ & $\begin{array}{l}\text { Bioactive } \\
\text { and }\end{array}$ & $\mathrm{C}_{8} \mathrm{H}_{17} \mathrm{~N}$ & 127 & 30.90 & 29.66 \\
\hline
\end{tabular}




\begin{tabular}{|c|c|c|c|c|c|c|c|}
\hline & & methyl- & antibacterial & & & & \\
\hline 7. & 24.200 & $\begin{array}{l}\text { 1,2- } \\
\text { Benzenedicarboxyli } \\
\text { c acid, diisooctyl } \\
\text { ester }\end{array}$ & $\begin{array}{l}\text { Antimicrobi } \\
\text { al, Anti } \\
\text { fouling }\end{array}$ & $\mathrm{C}_{2}{ }_{4} \mathrm{H}_{3} 8 \mathrm{O}_{4}$ & 390 & 1.94 & 3.42 \\
\hline 8. & 24.200 & $\begin{array}{l}\text { 1,2- } \\
\text { Benzenedicarboxyli } \\
\text { c acid, mono(2- } \\
\text { ethylhexyl) ester }\end{array}$ & $\begin{array}{l}\text { Antimicrobi } \\
\text { al, and } \\
\text { cytotoxicity }\end{array}$ & $\mathrm{C}_{16} \mathrm{H}_{22} \mathrm{O}_{4}$ & 278 & 1.94 & 3.42 \\
\hline
\end{tabular}

$\mathrm{RA}=$ peak area of each compound / the highest peak area $* 100$

\section{References}

1- Shepherd MD, Kharel MK, Bosserman MA, Rohr J. Laboratory maintenance of Streptomyces spp. Curr. Protoc. Microbiol. (2010); Chapter 10: Unit 10E.

2- Atta MA, Ahmad MS. Antimycin-A antibiotic biosynthesis produced by Streptomyces sp. AZ-AR-262: Taxonomy, fermentation, urification and biological activities. J Basic Sci. (2009); 3: 126-135.

3- Reddy NG, Ramakrishna DPN, Rajagopal SV. A morphological physiological and biochemical studies of Streptomyces rochei MTCC 10109 showing antagonistic activity against selective human pathogenic microorganisms. Asian J Biol Sci. (2011); 4:1-14.

4- Kieser T, Bibb MJ, Buttner MJ, Chater KF, Hopwood DA. Practical Streptomyces Genetics. (2000); Second Edition. Norwich, England: John Innes Foundation.

5- Singer RS, Finch R, Wegener HC, Bywater R, Walters J, lipsitch M. Antibiotic- resistance - the interplay between antibiotic use in animals and human beings. lancet Infect Dis. (2003); 3: 47-51.

6- Hakvag SE, Fjarvic KD, Josefsen E, Lan TE, Ellignsen, Zotchev SB. Characterization of Streptomyces spp. Isolated from the sea surface microlayer in the Trondheim Fjord, Norway. Mar drugs. (2008); (6): 620-635.

7- Al-Rubaye TS, Risan MH, Al-Rubaye D, Radi OR. Characterization of marine Streptomyces spp. bacterial isolates from Tigris river sediments in Baghdad city with Lc-ms and 1 HNMR, Journal of Pharmacognosy and Phytochemistry. (2018); 7(5): 2053-2060.

8- Al-Rubaye TS, Risan MH, Al-Rubaye D. Identification and in vitro Antimicrobial activity of marine Streptomyces spp. bacteria from Tigris river sediments in Baghdad city. WJPLS. (2018); 4(10):120-134.

9- Andrew M. Role of advances in chromatographic techniques in phytochemistry. Phytochemistry. (2007); 68: 2785-2797.

10- Kadhim MJ, Sosa AA, Hameed IH. Evaluation of anti-bacterial activity and bioactive chemical analysis of Ocimum basilicum using Fourier transform infrared (FT-IR) and gas chromatography-mass spectrometry (GC-MS) techniques. JPP. (2016); 8 (6): 127-146.

11- Abeer F, Imad HH, Mohanad JK. A Review: Uses of Gas Chromatography-Mass Spectrometry (GCMS) Technique for Analysis of Bioactive Natural Compounds of Some Plants. Int J Toxico and Pharma Res. (2017); 9 (1): 81-85.

12- Pandey A, Milind M, Naik DSK. Organic metabolites produced by Vibrio parahaemolyticus strain An3 isolated from Goan mullet inhibit bacterial fish pathogens. Goa, India. AJB., (2010); 9(42): 71347140. 
13- Nezhadali A, Nabavi M, Akbarpour M. Chemical composition of ethanol/n-hexane extract of the leaf from Tanacetum polycephalum subsp. duderanum as a herbal plant in Iran. Der Pharmacia Sinica. (2010); 1(3): 147-150.

14- Sathyaprabha G, Kumaravel S, Panneerselvam A. Bioactive Compounds Identification of Pleurotus platypus and Pleurotuseous by GC-MS. Adv Appl Sci Res. (2011); 2: 51.

15- Nandhini US, Sangareshwari S, Sangareshwari KL. Gas chromatography-Mass spectrometry analysis of bioactive constituents from the marine Streptomyces. Asian J. of Pharmaceu. and Clin. Res. (2015); 8 (2): 244-246.

16- Zhu H, Stephanie KS, Hye KK, Viviane C, da Cunha, Paolina G, Jos MR, Gilles P. van Wezel. Environmental and metabolomic study of antibiotic production by actinomycetes. Antimicrobial Effect of Volatile Organic Compounds Released by Metabolically Diverse Actinomycetes. Chapter 7. (2014); Leiden University dissertation.

17- Li P, Ma L, Feng YL, Mo MH, Yang FX, Dai HF, Zhao YX. Diversity and chemotaxis of soil bacteria with antifungal activity against Fusarium wilt of banana. J. Ind. Microbiol. Biot. (2012); 39(10): 1495- 1505.

18- Wilkins JPG. The analysis of pesticides \& related compounds using Mass Spectrometry. APPENDICES. GC-MS Guide, Ed4, Part I, Nov 1993 - (2015); ORCA.

19- Wu G, Nielson JR, Peterson RT, Winter JM. Bonnevillamides, Linear Heptapeptides Isolated from a Great Salt Lake-Derived Streptomyces spp. Marine drugs. (2017); 15 (7): 195.

20- Alva-Murillo N, Ochoa-Zarzosa A, López-Meza JE. Short chain fatty acids (propionic and hexanoic) decrease Staphylococcus aureus internalization into bovine mammary epithelial cells and modulate antimicrobial peptide expression. Vet. Microbiol. (2012); 155: 324-331.

21- Rousseau B, Dostal L, Rosazza JPN. Biotransformations of tocopherols by Streptomyces catenulae. Lipids. (1997); 32 (1): 79-84.

22- Cordovez V, Carrion VJ, Etalo DW, et al. Diversity and functions of volatile organic compounds produced by Streptomyces from a disease-suppressive soil. Front Microbiol. (2015); 6:1081.

23- Scholler CE, Gurtler H, Pedersen R, Molin S, Wilkins K. Volatile Metabolites from Actinomycetes. J. Agric. Food Chem. (2002); 50 (9): 2615-2621.

24- Thiericke R, Stellwaag M, Zeeck A, Snatzke G. The structure of manumycin. III. Absolute configuration and conformational studies. J Antibiot (Tokyo), (1987); 40 (11):1549-1554.

25- AL-Kateb H, Costello BL. Analysis of the volatiles in the headspace above the plasmodium and sporangia of the slime mould (Physarum polycephalum) by SPME-GCMS. arXiv preprint arXiv: (2013); 1307.8017.

26- Baskaran R, Mohan PM, Sivakumar K, Kumar A. Antimicrobial activity and phylogenetic analysis of Streptomyces parvulus dosmb-d105 isolated from the mangrove sediments of Andaman Islands. Acta Microbiologica et Immunologica Hungarica. (2016); 63: 27- 46.

27- Srikesavan S, Masilamani MS. Actinomycetes from marine sediment screening for cytotoxicity identification and analysis of bioactive constituents by GCMS. ICBBHS. (2012); 32-45. 